Gut, 1978, 19, 151-154

\title{
Effect of prolonged cimetidine therapy on gastric acid secretion in man
}

\author{
G. O. BARBEZAT ${ }^{1}$ AND S. BANK \\ From the Gastrointestinal Clinic and Department of Medicine, Groote Schuur Hospital and \\ University of Cape Town, South Africa
}

SUMMARY In a double blind trial, 23 patients with endoscopically confirmed duodenal ulceration received cimetidine ( $300 \mathrm{mg}$ four times daily in six patients, or $400 \mathrm{mg}$ four times daily in 10 patients) or placebo (seven patients) for six weeks. Before entry into the trial, pentagastrin $\left(6 \mu \mathrm{g} \cdot \mathrm{kg}^{-1} \cdot \mathrm{h}^{-1}\right)$ stimulated gastric acid secretion after a single oral dose of 300 or $400 \mathrm{mg}$ cimetidine was lowered by $82.1 \%$ and $81.0 \%$ respectively, while no significant inhibition was recorded in the patients receiving placebo $(8.8 \%)$. The same test repeated after six weeks of continuous-treatment showed that the effect of the drug was maintained, the percentage inhibition of acid secretion being of the same order as in the first test.

Histamine $\mathrm{H}_{2}$-receptor antagonists (Black et al., 1972) are potent inhibitors of gastric acid secretion in man, (Wyllie et al., 1972; Barbezat et al., 1974; Henn et al., 1975; Pounder et al., 1975; Richardson et al., 1976). Reports of their effective use in the treatment of duodenal ulcer have already been published (Multicentre Trial, 1975; Blackwood et al., 1976; Bodemar and Walan, 1976), but their long-term safety and efficacy have yet to be established. In a previous publication we demonstrated that metiamide retained its acid inhibiting action after one month's continuous treatment (Barbezat and Bank, 1976). In this study the effect on gastric acid secretion of two dose regimes of oral cimetidine or a placebo has been studied at the beginning and end of six weeks' continuous treatment in patients with endoscopically proven duodenal ulcers.

\section{Methods}

Studies were performed on 23 patients aged 19 to 62 years (mean 35 years) with uncomplicated duodenal ulcers. The ulcers were proved to be present by both radiology and endoscopy. Informed consent was obtained for the treatment trial (Bank et al., 1976) and the investigations. After a 10-hour overnight fast a nasogastric tube was positioned in the dependent

\footnotetext{
${ }^{1}$ Address for correspondence: Dr G. O. Barbezat, Gastrointestinal Clinic, Groote Schuur Hospital, Observatory, 7925, Cape. South Africa.
}

Received for publication 22 July 1977 part of the stomach and its position checked fluoroscopically. Fasting juice was aspirated and discarded. Basal secretions were collected for two 15 minute periods. Pentagastrin (Imperial Chemical Industries Ltd., Macclesfield, England) $\left(6 \mu \mathrm{g} . \mathrm{kg}^{-1} \cdot \mathrm{h}^{-1}\right)$ was then infused into a forearm vein using a Braun Unita 1 infusion pump (B. Braun, Melsungen, West Germany) for one hour. Gastric juice was aspirated by continuous mechanical aspiration with frequent manual clearing of the tube using a syringe. Collections were divided into 15 minute samples. At the end of the hour, $0 \cdot 15 \mathrm{M}-\mathrm{NaCl}$ was infused intravenously instead of the pentagastrin. Nasogastric aspiration was stopped. At this stage the patients received their first dose of randomly allocated trial therapy via the nasogastric tube-namely, cimetidine $300 \mathrm{mg}$ or cimetidine $400 \mathrm{mg}$ or placebo dissolved in $100 \mathrm{ml} 0.03 \mathrm{M}-\mathrm{HCl}$ containing ${ }^{14} \mathrm{C}$-polyethylene glycol $\left({ }^{14} \mathrm{C}-\mathrm{PEG}\right)(1.6 \mu \mathrm{C})$ as a non-absorbable marker. A $2 \mathrm{ml}$ aliquot was retained for isotope counting. The treatments were given double blind and corresponded to the treatments each patient was to receive for the following six weeks. After $11 / 2$ hours, gastric aspiration was restarted. Gastric contents were aspirated for five minutes to remove any residual acid or treatment solution. The next two 15 minute collections were retained as 'after treatment' basal secretion. The intravenous infusion of pentagastrin $\left(6 \mu \mathrm{g} \cdot \mathrm{kg}^{-1} \cdot \mathrm{h}^{-1}\right)$ was restarted and four 15 minute samples of gastric secretion collected. Each patient therefore acted as his own control, the first part of the test without cimetidine and the second after 
cimetidine. Results of the second half of the acid study were withheld from the clinical investigators who were monitoring the progress of each patient, as the degree of acid inhibition might have unblinded the patients receiving active treatment.

Aliquots of gastric aspirate from all samples collected after giving the treatments were examined for radioactivity using a Beckman LS-250 liquid scintillation system. The proportion of cimetidine which did not leave the stomach could therefore be assessed. The patients were then given cimetidine $300 \mathrm{mg}$ or $400 \mathrm{mg}$ or placebo four times daily, for six weeks. Specified antacid tablets were allowed for relief of symptoms, and the quantity of antacid taken was recorded on a diary card. Patients returned each week for interrogation, haematological and biochemical blood checks, and to obtain new supplies of cimetidine, at which time the number of tablets remaining were checked to ensure that the correct dose had been taken. At the end of six weeks' treatment, acid secretory studies were repeated following the same protocol. The patients were instructed not to take any treatment after the evening before the test, giving them a period of at least 14 hours without treatment before the acid study was performed.

Volumes of gastric juice were measured to the nearest millilitre and acid concentration measured by titration to $\mathrm{pH} 7$ against $0 \cdot 1 \mathrm{M}-\mathrm{NaOH}$ using an automatic titrator (Metrohm Ltd., Herisau, Switzerland). Volume and acid output during each 30 minute basal period were multiplied by 2 and expressed as $\mathrm{ml} / \mathrm{h}$ and $\mathrm{mmol} / \mathrm{h}$ respectively. Stimulated acid output represents the total acid output during the hour of pentagastrin stimulation. Changes in secretion in individual patients were compared using Student's $t$ test for paired values. The $t$ test for unpaired values was used to compare the difference between the two cimetidine treated groups of patients and the controls. Figures in parentheses after mean values represent the standard error of the mean (SEM).

\section{Results}

When the treatment code was broken at the end of the studies, it was found that seven patients had received placebo, six the lower and 10 the higher dose of cimetidine. There was no difference in the mean ages $(36 \pm 5 \cdot 2,38 \pm 4 \cdot 3$ and $33 \pm 2 \cdot 7$ years respectively) and mean body weights $(69.4 \pm 2 \cdot 4,60 \cdot 8 \pm$ 3.6 and $64.9 \pm 2.5 \mathrm{kgs}$ respectively) of the patients in each group.

Results of the acid studies are illustrated in the Figure. Basal gastric acid secretion was variable, but there was a clear trend for acid output to be lower two hours after the treatments were given. This
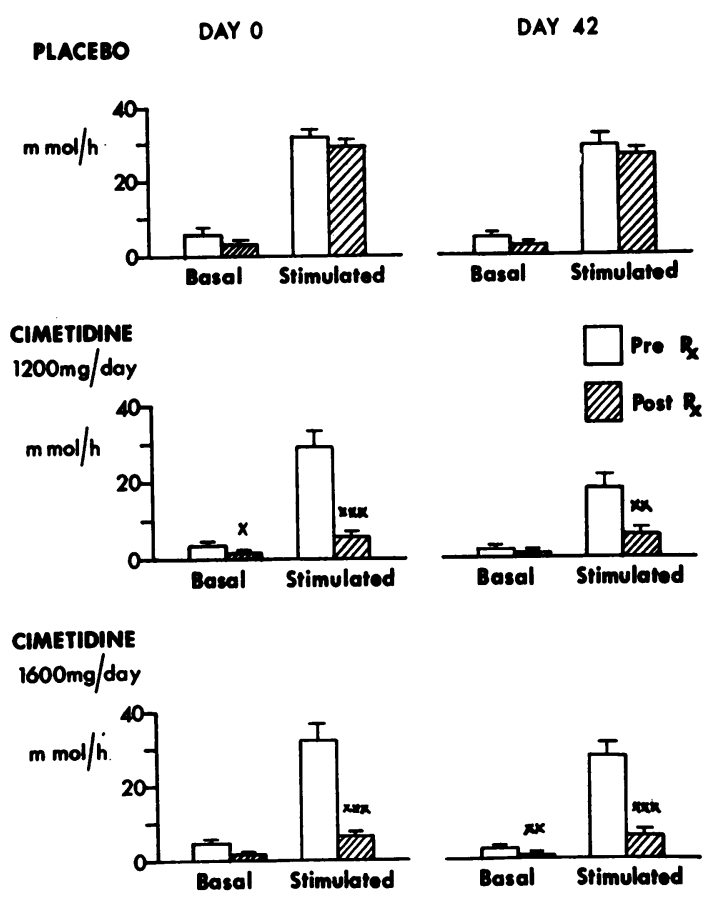

Figure Effect of one dose of cimetidine (300 $\mathrm{mg}$ or $400 \mathrm{~g}$ ) or placebo on basal and pentagastrin-stimulated gastric output. Day 0 indicates effect on acid secretion before any duodenal ulcer treatment, and day 42 the same test on the same patients the day after completing six weeks' continuous treatment with placebo $(n=7)$, cimetidine $1200 \mathrm{mg} /$ day $(n=6)$ or cimetidine $1600 \mathrm{mg} /$ day $(n=10) . \times: \mathrm{P}<0.02 . \times \times: \mathrm{P}<0.005 . \times \times \times$ : $\mathrm{P}<0.001$.

reached statistical significance with low dose cimetidine on day $0(P<0.02)$ and with high dose cimetidine on day $42(P<0.005)$. Patients receiving placebo also showed a drop in basal acid secretion during the second half of each study but these differences were not significant.

Both the lower and higher doses of cimetidine markedly inhibited the pentagastrin-stimulated gastric acid secretion, whether given on day $0(\mathrm{P}<$ 0.001 and $P<0.001$ respectively) or on day 42 ( $P<$ 0.005 and $P<0.001$ respectively). This resulted from significant depression of both volume output and acid concentration. Placebo did not affect stimulated acid secretion in any way. The percentage inhibition of stimulated acid output was similar for both treatment regimes $(82.1 \pm 3.1 \%$ for the lower dose and $81.0 \pm 3.5 \%$ for the higher dose) and this degree of inhibition was maintained when the tests were repeated on day $42(65.9 \pm 7 \cdot 3 \%$ and $79.4 \pm 3.7 \%$ respectively) (Table). The percentage inhibition appears to be a little less with the lower dose of 
Table Percentage inhibition of stimulated acid output

\begin{tabular}{llll}
\hline Day & \multicolumn{3}{l}{ Percentage inhibition } \\
\cline { 2 - 4 } & Placebo & Cimetidine \\
\cline { 2 - 4 } & & $1200 \mathrm{mg} /$ day & $1600 \mathrm{mg} /$ day \\
\hline 0 & $8 \cdot 8 \pm 10 \cdot 5^{*}$ & $82 \cdot 1 \pm 3 \cdot 1$ & $81.0 \pm 3.5$ \\
42 & $4.7 \pm 14.5^{*}$ & $65.9 \pm 7 \cdot 3$ & $79.4 \pm 3.7$ \\
\hline
\end{tabular}

${ }^{*} \mathbf{P}<0.001$ compared with both cimetidine treated groups.

cimetidine on day 42 , but there was no statistically significant difference between the effects of any of the active treatments. Conversely, patients receiving placebo showed negligible inhibition $(8.8 \pm 10.5 \%$ on day 0 and $4.7 \pm 14.5 \%$ on day 42 ) which contrasted sharply with those receiving active treatment (P $<0.001$ ).

The mean amount of ${ }^{14} \mathrm{C}$-PEG recovered from the stomach during the second half of each study was $6.75 \pm 1.01 \%$ of the given dose, indicating that more than $90 \%$ of the treatment effectively passed the pylorus to be absorbed in the small bowel. There was no difference in the recovery of marker between patients receiving placebo or either dose of cimetidine.

\section{Discussion}

This study has shown that cimetidine retains its acid inhibiting effect after six weeks of continuous treatment in patients with duodenal ulcers. Both volume output and acid concentration were lowered. Acid inhibition with cimetidine was consistently greater than the usual reduction after vagotomy (Gillespie and Kay, 1961; Bank et al., 1967; Schrumpf et al., 1974), and this was maintained as long as the patients took their medication. No patient was observed to 'escape' from the drug effect at the six week interval of this study, but the effect of longer periods of treatment will have to be assessed if the drug is to be used for maintenance prophylactic therapy.

Both the doses of cimetidine used in this study were equally effective in inhibiting gastric acid secretion (Table). Although there is a clear dose response relation between lower doses of cimetidine and gastric inhibition, the absence of such a relation with the doses used in this study ( 300 and $400 \mathrm{mg}$ ) may imply that maximal inhibition had been reached with the lower dose. Data are not available with higher orally administered doses of cimetidine to substantiate this observation.

Studies in rats have shown that continuous administration of very large doses of histamine $\mathrm{H}_{2^{-}}$ receptor antagonist for $\mathbf{1 8}$ days leads to an increase in the oxyntic gland area with a resulting higher gastric acid output (Halter and Witzel, in press). A rise in circulating gastrin levels may be suspected in these animals. This effect could not be confirmed under the conditions of the present study in man. No significant changes were observed in fasting serum gastrin levels spanning the duration of the present study (Bank et al., 1977). In previous acute studies, we have shown that histamine $\mathrm{H}_{2}$-receptor blockade alone does not effect blood gastrin levels but that a meal taken after the antagonist produces marginally but significantly higher blood gastrin levels than those reached after a meal not preceded by an antagonist (Barbezat et al., 1975).

Patients receiving the lower dose of cimetidine were in fact noted to have a lower mean acid output after their six weeks of treatment than when they were entered into the trial (Figure) and this was statistically significant $(P<0.05)$. Although care was taken in ascertaining when the patients had taken their last dose of treatment it is possible that this represents a residual effect from their previous evening's dose or, in fact, that they took their usual early morning dose of treatment. The half-life of cimetidine is of the order of two hours in man (Brimblecombe et al., 1975), making the latter explanation more likely. It is noteworthy that this difference was not observed with the larger cimetidine dose $(t=0.694, \mathrm{P}>0.40)$ where this should have been more pronounced if the drug produced any permanent changes in parietal cell reactivity or if it had a cumulative effect. The explanation for this nevertheless remains unknown.

The effect on basal acid secretion, difficult to interpret in man, was very variable in the present study. The method of study is not ideally designed for measurement of changes in basal secretion as the second basal collection period occurs $11 / 2$ hours after an infusion of pentagastrin. This factor would lead to an underestimation of drug efficacy. The slight rise in basal acid secretion after the drug treatment noted in a few studies is therefore attributed to the method of study rather than to an effect of the drug. Despite this, basal acid secretion was lowered by cimetidine and this was significant with the small dose on day 0 and with the larger dose on day 42 . Separate studies performed in this laboratory (Barbezat and Bank, 1977) and elsewhere (Bodemar and Walan, 1976) have confirmed that cimetidine is an effective inhibitor of basal gastric acid secretion in man.

The mean gastric emptying of ${ }^{14} \mathrm{C}-\mathrm{PEG}$ at $11 / 2$ hours was virtually identical on day 0 when all the patients had active duodenal ulcers and on day $\mathbf{4 2}$ when $70 \%$ of the patients had healed their ulcers $(13$ of the 16 receiving the cimetidine and three of the seven receiving placebo) (Bank et al., 1976). This 
indicates that the effective dose of drug administered was the same at the beginning and end of treatment, and also that there was no significant degree of gastric fluid retention in these patients.

Haematology and blood biochemistry was monitored weekly in all our patients. No significant sideeffects were observed. Long-term therapy with cimetidine seems justified on the gounds that it remains a potent inhibitor of gastric acid secretion despite prolonged use, and that administration of the drug is associated with significant healing of duodenal ulcers. A reversible highly effective method of acid reduction is now available, although the safety and efficacy of this can be settled only with further experience and careful monitoring during extended long-term trials.

We wish to thank Mrs S. Bridger and Mrs T. Strano for expert technical assistance, and Dr I. N. Marks for critical review of the manuscript. Cimetidine was provided by Smith Kline and French (Pty) Ltd. Financial assistance was provided by the South African Medical Research Council.

\section{References}

Bank, S., Barbezat, G. O., Novis, B. H., Ou Tim, L., Odes, S., Helman, C., Narunsky, L., Duys, P. J., and Marks, I. N. (1976). Histamine $\mathbf{H}_{2}$-receptor antagonists in the treatment of duodenal ulcers. South African Medical Journal, 50, 1781-1785.

Bank, S., Barbezat, G. O., Vinik, A. I., and Helman, C. (1977). Serum gastrin levels before and after 6 weeks of cimetidine therapy in patients with duodenal ulcer. Digestion, 15, 157-161.

Bank, S., Marks, I. N., and Louw, J. H. (1967). Histamineand insulin-stimulated gastric acid secretion after selective and truncal vagotomy. Gut, 8, 36-41.

Barbezat, G. O., and Bank, S. (1976). The effect of prolonged metiamide administration on gastric acid secretion in man. American Journal of Digestive Diseases, 21, 473-476.

Barbezat, G. O., and Bank, S. (1977). Basal acid output response to cimetidine in man. In Cimetidine: Proceedings of the Second International Symposium on Histamine $\mathrm{H}_{2}$ Receptor Antagonists, London, October, 1976, pp. 110-119.
Edited by W. L. Burland and M. A. Simkins. Excerpta Medica: Amsterdam.

Barbezat, G. O., Bank, S., Clain, J., Novis, B., and Marks, I. N. (1974). Oral metiamide as an effective inhibitor of gastric acid secretion in man. South African Medical Journal, 48, 2018-2020.

Barbezat, G. O., Grant, B., Bank, S., and Vinik, A. I. (1975). The effect of histamine $\mathbf{H}_{2}$-receptor blockade with metiamide on serum gastrin levels in man. Gut, 16, 186-187.

Black, J. W., Duncan, W. A. M., Durant, C. J., Ganellin, C. R., and Parsons, E. M. (1972). Definition and antagonism of histamine $\mathrm{H}_{2}$-receptors. Nature (Lond.), 236, 385390.

Blackwood, W. S., Maudgal, D. P., Pickard, R. G., Lawrence, D., and Northfield, T. C. (1976). Cimetidine in duodenal ulcer: controlled trial. Lancet, 2, 174-176.

Bodemar, G., and Walan, A. (1976). Cimetidine in the treatment of active duodenal and prepyloric ulcers. Lancet, 2 , 161-164.

Brimblecombe, R. W., Duncan, W. A. M., Durant, C. J., Emmett, J. C., Ganellin, C. R., and Parsons, M. E. (1975). Cimetidine-a non-thiourea $\mathbf{H}_{2}$-receptor antagonist. Journal of International Medical Research, 3, 86-92.

Gillespie, I. E., and Kay, A. W. (1961). Effect of medical and surgical vagotomy on the augmented histamine test in man. British Medical Journal, 1, 1557-1560.

Halter, F., and Witzel, L. Increased acid secretion after sustained metiamide medication in the rat. Gastroenterology, (In press.)

Henn, R. M., Isenberg, J. I., Maxwell, V., and Sturdevant, R. A. L. (1975). Inhibition of gastric acid secretion by cimetidine in patients with duodenal ulcer. New England Journal of Medicine, 293, 371-375.

Multicentre Trial (1975). Treatment of duodenal ulcer by metiamide. Lancet, 2, 779-781.

Pounder, R. E., Williams, J. G., Milton-Thompson, G. J., and Misiewicz, J. J. (1975). 24-hour control of intragastric acidity by cimetidine in duodenal-ulcer patients. Lancet, 2 , 1069-1072.

Richardson, C. T., Walsh, J. H., and Hicks, M. I. (1976). The effect of cimetidine, a new histamine $\mathrm{H}_{2}$-receptor antagonist, on meal-stimulated acid secretion, serum gastrin, and gastric emptying in patients with duodenal ulcer. Gastroenterology, 71, 19-23.

Schrumpf, E., Roland, M., and Liavag, I. (1974). Serum gastrin and gastric acid secretion before and after proximal gastric vagotomy. Scandinavian Journal of Gastroenterology, 9, 115-118.

Wyllie, J. H., Hesselbo, T., and Black, J. W. (1972). Effects in man of histamine $\mathrm{H}_{2}$-receptor blockade by burimamide. Lancet, 2, 1117-1120. 